\title{
PENGARUH KETERLIBATAN ORANG TUA TERHADAP HASILPEKERJAAN RUMAH SISWA KELAS V SEKOLAH DASAR
}

\author{
Fembriani $^{1}$, Adriana Selly ${ }^{2}$ \\ 1,2 Program Studi Pendidikan Guru Sekolah Dasar, Universitas Nusa Cendana \\ Fembriani@staf.undana.ac.id
}

\section{INFO ARTIKEL}

\section{Riwayat Artikel:}

Diterima: 06-Januari-2021

Disetujui: 30-Maret-2021

\section{Kata Kunci:}

Keterlibatan, Orang tua, Hasil pekerjaan rumah

\begin{abstract}
ABSTRAK
Abstrak: Penelitian ini untuk melihat apakah ada pengaruh yang signifikan antara keterlibatan orang tua terhadap hasil pekerjaan rumah siswa kelas V Sekolah Dasar Negeri Oebobo 2 Kupang. Tujuan penelitian ini untuk mengetahui pengaruh keterlibatan orang tua terhadap hasil pekerjaan rumah siswa kelas V Sekolah Dasar. Metode penelitian yang digunakan adalah metode survei. Teknik pengumpulan datanya menggunakan teknik angket, wawancara sebagai instrumen utama dan studi dokumentasi yang berhubungan dengan hasil pekerjaan rumah siswa. Teknik analisis data yang digunakan yakni analisis deskriptif kuantitatif dengan jumlah responden yang di teliti 26 orang terdiri dari 11 laki-laki dan 15 perempuan. Penelitian ini diadakan di SD Negeri Oebobo 2 Kupang, dengan hasil penelitian menunjukkan bahwa: nilai signifikansi sebesar 0,001 . Oleh karena $0,001<0,05$, maka HO ditolak dan Ha di terima, sehingga dapat dinyatakan bahwa terdapat pengaruh yang signifikan antara keterlibatan orang tua dengan hasil pekerjaan rumah siswa. Dari hasil analisis juga didapatkan nilai sebesar 119,00 yang artinya siswa dengan kurang mendapatkan keterlibatan orang tua dalam mengerjakan tugas memiliki resiko 119 kali untuk mendapatkan nilai dengan kategori kurang baik. Berdasarkan hasil penelitian di atas maka dapat disimpulkan bahwa keterlibatan orang tua memiliki pengaruh terhadap hasil pekerjaan rumah siswa kelas V SD N Oebobo 2 Kupang.
\end{abstract}

\begin{abstract}
This research aims to find out a significant influence between the involvement of parents on the homework results of the fifth grade students of Oebobo 2 Kupang Elementary School. The research method used is a survey method. The data collection technique used a questionnaire technique, interviews as the main instrument and study documentation related to the results of student homework. The data analysis technique used was descriptive quantitative analysis with the number of respondents studied were 26 people consisted of 11 men and 15 women This research was conducted at Oebobo 2 Kupang Elementary School with the results of the study showing that: the significance value is 0.001 . Because $0.001<0.05$, then $\mathrm{HO}$ is rejected and Ha is accepted, so it can be stated that there is a significant influence between parental involvement and the results of student homework. From the results of the analysis also obtained an OR value of 119.00, which means that students with less parental involvement in doing assignments have a 119 times risk of getting a score in the bad category. Based on the results of the research above, it can be concluded that the involvement of parents has an influence on the homework results of the fifth grade students of Oebobo 2 Kupang Elementary School
\end{abstract}

\section{A. LATAR BELAKANG}

Keluarga merupakan tempat pertama dan utama bagi anak dalam belajar dan mendapatkan pendidikan. Keluarga dalam pandangan antropologi adalah kesatuan-kesatuan kecil yang memiliki tempat tinggal dan di tandai oleh kerja sama yang sangat erat dimana orang tua (ayah dan ibu) mempunyai kewajiban dan tanggung jawab untuk mendidik anak-anaknya. Sutardi (2007) mengutarakan keluarga mempunyai pengaruh penting dalam pendidikan anak. Keluarga sebagai tempat pendidikan yang paling utama dan paling penting disebabkan karena dalam keluarga anak dilahirkan dan tumbuh menjadi dewasa,bentuk pendidikan dalam keluarga akan selalu mempengaruhi pertumbuhan dan perkembangan watak, budi pekerti, dan kepribadian anak. Bentuk pendidikan juga tidak terlepas dariperhatian, dukungan serta keterlibatan yang maksimal dalam proses anak dalam belajar, terkhususnya pada tugas tambahan atau pekerjaan rumah yang diberikan bagi anak pada pendidikan formalnya. Syamsi (2015) berpendapat pekerjaan rumah adalah tugas mandiri terstruktur yang diberikan guru untuk dikerjakan dirumah sebagai latihan tambahan. Pekerjaan rumah juga dapat diartikan sebagai salah satu bentuk metode mengajar yang berguna untuk mengatasi kelemahan metode-metode lain 
(seperti ceramah, diskusi, dan lain lain) dalam hal pemahaman para siswa terhadap materi pelajaran. Metode ini juga dapat di artikan sebagai suatu cara menyampaikan dan memberi pemahaman kepada para siswa melalui pemberian tugas. Penggunaan metode pembelajaran pemberian tugas rumah yang diberikan oleh guru di sekolah sangat efektif guna mendorong para siswa belajar di luar jam sekolah, baik perorangan maupun kelompok. Keterlibatan orang tua dalam membantu belajar anak di luar jam sekolah atau lebih tepatnya di rumah sangatlah diperlukan. Karena disamping keluarga menjadi pendidik yang utama dan pertama pada anak, siswa lebih banyak mempunyai waktunya di rumah bersama orang tua dari pada di lingkungan sekolah. Karena itu tanpa adanya bantuan orang tua terhadap aktivitas belajar anak dalam mengerjakan tugas di rumah mustahil akan diperoleh prestasi belajar yang optimal bagi anak.

Keterlibatan orang tua dalam belajar anak dirumah terkhususnya pada pengerjaan tugas tambahan bukan merupakan pekerjaan yang mudah, perhatian dari orang tua terhadap pendidikan anak dalam rumah tangga sangat menentukan keberhasilan anak dalam belajar, hal ini memberikan dampak positif terhadap perubahan tingkah laku dan perkembangan pendidikan anak. Orang tua memperhatikan cara belajar anak dirumah sehingga anak memperoleh prestasi belajar yang baik disekolah. Keterlibatan orang tua dalam memberikan bimbingan di rumah, memperhatikan dan mendukung anak dalam mengerjakan tugas, memberi perhatian dan motivasi, mengatur disiplin anak dalam belajar dan sebagainya akan sangat penting bagi anak dalam pendidikannya. Jika hal ini tidak dapat dilakukan orang tua maka anak akan mengalami kesulitan dalam belajar dan mengerjakan pekerjaan rumah misalnya anak akan merasa malas dalam mengerjakan pekerjaan rumah bahkan tidak mempunyai waktu dalam belajar sehingga akan sangat berpengaruh pada hasil belajarnya disekolah.

Keterlibatan orang tua terhadap anak sering dipengaruhi oleh sikap dan tanggung jawab orang tua dalam memberikan bimbingan dan pembinaan kepada anak sehingga cara perlakuan orang tua merupakan salah satu penentu kepribadian anak itu sendiri. Cara perlakuan yang salah atau kurangnya keterlibatan orang tua maka akan timbul kekacauan bahkan malas dalam melakukan sesuatu. Begitupun sebaliknya cara perlakuan yang baik akan menempatkan diri anak pada kesadaran diri dalam melakukan sesuatu yang baik yang akan membuahkan hasil yang memuaskan. Maka dengan demikian orang tua memiliki tanggung jawab untuk mendidik dan mengasuh anak-anaknya agar menjadi lebih matang,berkelakuan baik serta memiliki wawasan yang luas. Di samping itu orang tua bertanggung jawab dalam melibatkan diri dalam belajar anak agar kedepan mampu menjalani kehidupan yang lebih baik kelak nanti (Ummu, Suryadin, et al., 2020)

Berdasarkan penjelasan di atas, dapat dipahami bahwa hasil belajar anak di sekolah terkhususnya pada keberhasilan anak dalam menyelesaikan pekerjaan rumahnya sangat dipengaruhi oleh adanya peran yang maksimal dari orang tua terhadap belajar anak. Peran orang tua sebagai pemberi perhatian, dukungan, kepedulian terhadap belajar dan melibatkan diri dalam menyelesaikan pekerjaan rumah sangat menunjang keberhasilan anak dalam belajarnya, namun kebanyakan orang tua ingin sekali agar anak-anaknya mencapai prestasidi sekolah.Tetapi orang tua mempunyai kesukaran untuk mewujudkan keinginannya itu. Keinginan agar anak berprestasi seperti yang diharapkan. Keinginan yang kuat dari orang tua,tetapi orang tua tidak berbuat sesuatu yang efektif dalam membimbing, mendorong dan melibatkan diri dalam menyelesaikan pekerjaan rumah siswa, karena belajar dirumah, merupakan suatu hal yang tidak selalu dilakukan oleh anak-anak masa kini yang dominannya adalah bermain sehingga, hal ini tidak akan berhasil kalauorang tua itu sendiri mempunyai waktu yang terbatas dan tidak melibatkan diri dalam menyelesaikan pekerjaan rumah siswa maka akan berdampak pada hasil pekerjaan rumah siswa di sekolah.

Berdasarkan hasil pengamatan yang dilakukan penulis terhadap siswa kelas V SD Negeri Oebobo 2 Kupang selama masa PPL dalam jangka waktu 5 bulan terdapat masalah hasil belajar siswa menurun. Salah satu faktor penyebabnya dikarenakan nilai pekerjaan rumah siswa kurang memuaskan atau dibawah rata-rata yang diharapkan karena sebagian besar tidak mengerjakan tugas rumah yang diberikan oleh guru. Hasil belajar yang di peroleh 26 siswa yakni 15 siswa tergolong dalam ketuntasan hasil belajarnya di karenakan adanya keterlibatan orang tua yang berperan dalam pengerjaan tugas dan belajar siswa di rumah. Adapun 11 siswa tergolong tidak Tuntas hal ini disebabkan karena kurangnya dorongan dan motivasi yang baik dari diri anak bahkan yang paling terpenting adalah kurangnya peran orang tua dalam mendukung, memotivasi serta melibatkan diri dalam menyelesaikan pekerjaan rumah, sehingga berpengaruh pada hasil belajar siswa disekolah.

Untuk melihat sejauh mana pentingnya keterlibatan orang tua dalam pendidikan anaknya, ada beberapa penelitian yang mengungkap variabel yang hampir sama telah dilakukan sebelumnya yaitu penelitian dari Ema Putri (2015) dari Universitas Negeri Semarang dengan judul " Pengaruh Keterlibatan Orang Tua dalam Belajar Terhadap Prestasi Belajar Siswa" hasil penelitian menunjukan terdapat pengaruh yang signifikan antara keterlibatan orang tua dalam belajar terhadap prestasi belajar siswa dan Penelitian yang dilakukan oleh Rini dan Suci (2016) menunjukkan pengaruh Partisipasi Orang Tua Terhadap Motivasi Belajar Siswa" memperoleh hasil ada pengaruh yang positif antara partisipasi orang tua terhadap motivasi belajar siswa. Dari kedua hasil penelitian tersebut dapat disimpulkan bahwa betapa pentingnya keterlibatan orang tua dalam pendidikan anak 
dirumah. Keterlibatan orang tua sebagai pemberi perhatian, motivasi dan dukungan bahkan terlibat dalam mengatasi masalah belajar anak, niscaya anak akan memberikan hasil yang terbaik.

Berdasarkan latar belakang masalah pentingnya keterlibatan orang tua, maka penulis tertarik untuk mengkaji masalah tersebut dengan melakukan penelitian tentang "Pengaruh Keterlibatan Orang Tua Terhadap Hasil Pekerjaan Rumah Siswa Kelas V SD Negeri Oebobo 2 Kupang.

\section{B. METODE PENELITIAN}

Penelitian ini menggunakan jenis penelitian kuantitatif dengan metode penelitian survei. Menurut (Meleong, 2009) menjelaskan "Penelitian survei adalah penelitian yang dilakukan pada populasi besar maupun kecil, tetapi data yang dipelajari adalah data dari sampel yang diambil dari populasi tersebut, sehingga ditemukan kejadiankejadian relatif, distribusi dan hubungan antarvariabel sosiologis maupun psikologis".

Dalam penelitian ini, peneliti melakukan penelitian survei tentang Pengaruh keterlibatan orang tua terhadap hasil pekerjaan rumah siswa kelas V SD N Oebobo 2 Kupang. Populasi adalah wilayah generalisasi yang terdiri atas : obyek/ subyek yang mempunyai kuantitas dan karakteristik tertentu yang ditetapkan oleh peneliti untuk dipelajari dan kemudian ditarik kesimpulannya (Sugiono, 2011). Yang menjadi populasi dalam penelitian ini adalah seluruh siswa kelas V SD N Oebobo 2 Kupang berjumlah 26 siswa. Sampel adalah bagian dari jumlah dan karakteristik yang dimiiliki oleh populasi tersebut. Dalam penelitian ini teknik sampling yang digunakan adalah Sampling Jenuh. Sampling Jenuh adalah teknik pengambilan sampel apabila semua populasi digunakan sebagai sampel. Sampling jenuh dilakukan apabila populasinya kurang dari 30 orang (Sugiono, 2011). Maka dengan demikian sampel yang digunakan adalah sampel populatif yang diteliti berjumlah 26 siswa dengan rincian laki-laki 11 orang dan perempuan 15 orang.

Dalam penelitian ini, peneliti menggunakan instrumen nontes. Instrumen nontes yang digunakan dalam penelitian ini adalah angket atau kuesioner. Angket atau kuesioner adalah daftar pertanyaan tertulis kepada sejumlah subjek untuk memperoleh tanggapan, informasi, jawaban dan sebagainya dari responden dalam arti laporan tentang pribadinya, atau hal-hal yang ia ketahui (Notoatmodjo, 2012).

Berdasarkan judul yang telah ditetapkan, penelitian ini menggunakan instrumen jenis skala. Skala yang digunakan dalam penyusunan angket adalah skala Guttman dengan alternatif penilaian yaitu 'YA dan TIDAK'. Skala Guttman dilakukan untuk mendapatkan jawaban yang tegas terhadap suatu permasalahan yang ditanyakan (Sugiono, 2011).

\section{HASIL DAN PEMBAHASAN \\ Hasil}

Populasi dan sampel yang digunakan dalam kegiatan penelitian adalah seluruh siswa kelas $\mathrm{V}$ yang berjumlah 26 siswa dengan rincian laki-laki 11 orang dan perempuan 15 orang. Proses kegiatan penelitian berlangsung selama 2 bulan terhitung bulan September - Oktober dengan cara membagi angket/kuesioner kepada seluruh siswa kelas V SD Negeri Oebobo Kupang untuk di isi dengan tujuan untuk mencaritau pengaruh keterlibatan orang tua dalam mengerjakan pekerjaan rumah siswa selain dari pada angket/ kuesioner adapun wawancara terstruktur yang disiapkan peneliti untuk mencari tau secara detail atau rinci terkait setiap pertanyaan yang termuat dalam angket/kuesioner.

Angket diisi oleh siswa untuk mengetahui keterlibatan orang tua saat siswa mengerjakan pekerjaan rumah mereka. Analisis data dimulai dengan menguji validitas angket. Validitas angket dihitung dengan uji validitas isi menggunakan rumus R11, Angket dikatakan valid jika nilai Rhitung > Rtabel dengan nilai Rtabel=0,3739 $(0,374)$.

Tabel 1. Uji Validitas

\begin{tabular}{cccc}
\hline No & R hitung & R tabel & Keterangan \\
\hline 1 & 0,734 & 0,3739 & Valid \\
2 & 0,513 & 0,3739 & Valid \\
3 & 0,516 & 0,3739 & Valid \\
4 & 0,506 & 0,3739 & Valid \\
5 & 0,808 & 0,3739 & Valid \\
6 & 0,793 & 0,3739 & Valid \\
7 & 0,567 & 0,3739 & Valid \\
8 & 0,643 & 0,3739 & Valid \\
9 & 0,589 & 0,3739 & Valid \\
10 & 0,763 & 0,3739 & Valid \\
11 & 0,458 & 0,3739 & Valid \\
12 & 0,522 & 0,3739 & Valid \\
13 & 0,573 & 0,3739 & Valid \\
14 & 0,602 & 0,3739 & Valid \\
\hline
\end{tabular}




\begin{tabular}{llll}
\hline 15 & 0,740 & 0,3739 & Valid \\
16 & 0,707 & 0,3739 & Valid \\
17 & 0,763 & 0,3739 & Valid \\
18 & 0,458 & 0,3739 & Valid \\
19 & 0,573 & 0,3739 & Valid \\
20 & 0,536 & 0,3739 & Valid \\
\hline
\end{tabular}

Dari tabel 1 hasil validasi diatas menunjukan nilai $\mathrm{R}$ hitung dari nomor pertanyaan 1 sampai dengan 20 memiliki nilai $R_{\text {hitung }}>R_{\text {tabel, }}$ maka dapat disimpulkan bahwa semua pertanyaan yang digunakan untuk penelitian dikatakan valid. Hal ini berarti semua angket dapat digunakan untuk penelitian.

Uji analisis selanjutnya dengan uji Reliabilitas. Angket / kuesioner dikatakan reliabilitas jika nilai Rhitung (R11 / a) > Rtabel atau sama dengan (=) 0,9.

\begin{tabular}{cc}
\multicolumn{2}{c}{ Tabel 2. Uji Reliabilitas } \\
\hline Cronbach's Alpha & N of Items \\
\hline, 914 & 20 \\
\hline
\end{tabular}

Dari tabel hasil reliabilitas menunjukan 20 item pertanyaan dengan nilai $R_{\text {hitung }}>R_{\text {tabel }}(0,914>0,9)$ sehingga angket dikatakan reliabilitas dengan kategori sangat tinggi.

Setelah Angket dinyatakan valid dan reliable, peneliti melaksanakan penelitian dengan angket tersebut untuk melihat pengaruh keterlibatan orangtua terhadap pekerjaan rumah siswa. Penelitian dilaksanakan pada siswa kelas V SD Oebobo Kupang. Peneliti melaksanakan penelitian dengan pengisian angket kepada siswa dengan tetap mendampingi siswa dalam mengisi angket tersebut untuk memperkecil kesalahan pemahaman siswa. Hasil pengisian angket selanjutnya dianalisis untuk melihat hasilnya. Sebelum melaksanakan pengujian hipotesis untuk melihat pengaruh, penelitian dimulai dengan uji normalitas data sebagai uji prasyarat.

Pengujian normalitas dilakukan untuk mengetahui data termasuk data normal atau data tidak normal. Pengujian normalitas menggunakan rumus Shapiro-Wilkdengan bantuan SPSS, maka didapatkan hasil sebagai berikut.

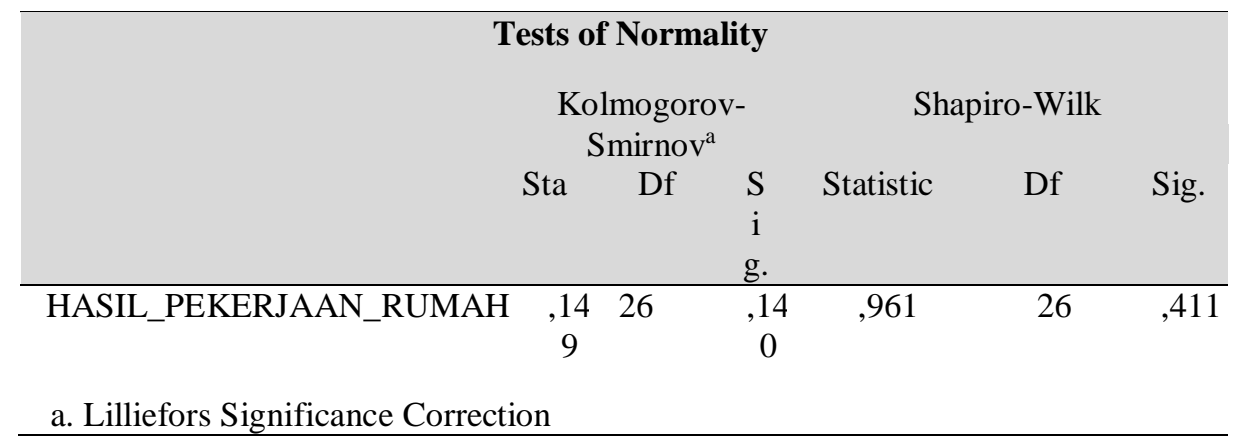

Dari uji normalitas data di atas didapatkan nilai signifikansi 0,411 lebih besar dari 0,05(p>0,05), untuk melihat data berdistribusi normal atau tidak dapat dilihat pada nilai signifikan pada hasil hitung yang akan di hubungkan dengan nilai a atau nilai tabel, Jika signifikansi kurang dari 0,05 maka data tidak berdistribusi normal. Tetapi jika nilai signifikansi lebih dari 0,05, maka data berdistribusi normal (Ummu, Sunimbar, et al., 2020). dari hasil uji di atas maka dapat disimpulkan bahwa data berdistribusi normal pada uji Shapiro-Wilk.

Uji hipotesis menggunakan uji analisis bivariat digunakan untuk melihat hubungan atau korelasi antara dua variabel. Hasil pengujian korelasi untuk melihat hubungan keterlibatan orang tua dengan hasil pekerjaan rumah siswa menggunakan program SPSS dengan hasil sebagai berikut:

Tabel 4. Analisis hubungan keterlibatan orang tua dengan hasil pekerjaan rumah siswa kelas V SDN

Oebobo 2 Kupang

\begin{tabular}{llllllll}
\hline & & B & S.E. & Wald & df & Sig. & $\operatorname{Exp(B)}$ \\
\hline Step & KETERLI & 4,7 & 1,48 & 10,374 & 1 &, 001 & 119,000 \\
$1^{\text {a }}$ & BATAN_- & 79 & 4 & & & & \\
& ORANG_ & & & & & & \\
& TUA & & & & & & \\
& Constant & - & 2,37 & 8,033 & 1 &, 005 &, 001 \\
& & 6,7 & 3 & & & & \\
\hline
\end{tabular}


Tabel di atas menunjukan bahwa dari hasil uji regresi logistik sederhana atau analisis akhir antara keterlibatan orang tua dengan hasil pekerjaan rumah siswa didapatkan nilai $p$ value $0,001(p<0,05)$ yang artinya Ha di terima dan Ho di tolak sehingga ada pengaruh yang signifikan antara keterlibatan orang tua dengan hasil pekerjaan rumah siswa kelas V SDN Oebobo 2 Kupang, dari hasil analisis didapatkan nilai OR sebesar 119,00 yang artinya siswa dengan kurang mendapatkan keterlibatan orang tua dalam mengerjakan tugas memiliki pengaruh 119 kali untuk mendapatkan nilai dengan kategori kurang baikdan mempunyai peluang sebesar $87 \%$.

\section{Pembahasan}

Dari hasil validasi menunjukan nilai Rhitung dari nomor pertanyaan 1 sampai dengan 20 memiliki nilai Rhitung > R tabel, maka dapat disimpulkan bahwa semua pertanyaan yang digunakan untuk penelitian dikatakan valid. Hasil reliabilitas menunjukan 20 item pertanyaan dengan nilai Rhitung $>$ Rtabel $(0,914>0,9)$ sehingga angket dikatakan reliabel. Uji linearitas diatas menunjukan nilai signifikan dari kedua variabel ( keterlibatan orang tua dan hasil pekerjaan rumah) memiliki nilai 0,000 lebih kecil atau lebih kurang dari 0.05 sehingga kedua variabel tersebut memiliki hubungan yang linear.

Dari hasil pengisian angket 26 responden menunjukan sebagian besar responden kurang mendapatkan keterlibatan orang tua dalam mengerjakan pekerjaan rumah yang diberikan oleh guru yaitu sebanyak 18 responden $(69,2 \%)$ dan sebagian kecil responden memiliki keterlibatan orang tua dalam mengerjakan pekerjaan rumah yang di berikan oleh guru yaitu sebanyak 8 responden $(30,8 \%)$ yang dijelaskan pada penjelasan tabel karakteristik responden berdasarkan keterlibatan orang tua, kemudian sebagian besar responden memiliki hasil pekerjaan rumah dengan kategori kurang baik yaitu sebanyak 18 responden $(69,2 \%)$ dan sebagian kecil responden memiliki hasil pekerjaan rumah dengan kategori baik yaitu sebanyak 8 responden $(30,8 \%)$.

Berdasarkan hasil uji regresi logistik sederhana antara keterlibatan orang tua dengan hasil pekerjaan rumah siswa didapatkan nilai $\mathrm{p}$ value $0,001(\mathrm{p}<0,05)$ hal ini berarti Ho ditolak dan Ha diterima karena nilai signifikannya lebih kecil dari 0,05 maka dengan demikian ada pengaruh yang signifikan antara keterlibatan orang tua dengan hasil pekerjaan rumah siswa kelas V SDN Oebobo 2 Kupang, dari hasil analisis didapatkan nilai OR sebesar 119,00 yang artinya siswa dengan kurang mendapatkan keterlibatan orang tua dalam mengerjakan tugas memiliki resiko 119 kali untuk mendapatkan nilai dengan kategori kurang baik dan mempunyai peluang sebesar $87 \%$.

Dari hasil uji regresi juga memiliki hubungan yang sangat erat dengan hasil wawancara, dimana hasil wawancara yang diperoleh sebagian besar responden ternyata kurang dalam mendapatkan keterlibatan orang tua dalam belajar dan mengerjakan pekerjaan rumah. Penelitian (Dian \& Ummu, 2020) mengemukan peran orang orang tua juga sangat penting dalam meningkatkan prestasi belajar peserta didik di sekolah dan hal ini juga didukung oleh pendapat dari Kenzi sebagai responden pertama yang mengatakan bahwa proses pembelajaran dirumah orang tua tidak memberikan jam tersendiri untuk belajar dirumah, orang tua juga minim dalam menyiapkan buku-buku paket lain untuk penunjang belajar, orang tua selalu mengingatkan untuk belajar namun tidak membantu dalam proses pembelajaran, orang tua selalu saja marah ketika hanya bersantai namun tidak perna memberikan semangat. Orang tua terkadang lupa membelikan buku tulis, orang tua tidak mengingatkan siswa untuk belajar, karena kesibukan pekerjaan yang membuat orang tua juga tidak punya waktu dalam membantu mengerjakan kesulitan PRnya. Terkadang orang tua memberikan semangat namun tidak memberikan hadiah sebagai salah satu bentuk motivasi untuk tetap semangat dalam belajar sehingga dari kebiasaan tersebut menyebabkan hasil pekerjaannya menurun. Dari hasil pembahasan di atas dapat disimpulkan bahwa betapa pentingnya keterlibatan orang tua yang akan berpengaruh pada hasil belajar siswa, di dukung dengan pendapat dari (Kadir, 2012) yang mengatakan bahwa orang tua bertanggung jawab dalam melibatkan diri dalam belajar anak agar anak memperoleh hasil yang baik dan kedepan mampu menjalani kehidupan yang lebih baik kelak nanti.

\section{SIMPULAN DAN SARAN}

Berdasarkan hasil penelitian yang berjudul "pengaruh keterlibatan orang tua terhadap hasil pekerjaan rumah siswa" dapat disimpulkan bahwa: Terdapat pengaruh yang signifikan antara keterlibatan orang tua dengan hasil pekerjaan rumah siswa kelas V SDN Oebobo 2 Kupang dengan hasil analisis uji regresi logistik sederhana menunjukan nilai $p$ value $=0,001(p<0,05)$. Hal ini berarti Ho ditolak karena nilai signifikannya lebih kecil dari 0,05 dan nilai OR atau besar pengaruhnya $=119,00$ yang artinya siswa yang kurang mendapatkan keterlibatan orang tua dalam mengerjakan tugas memiliki pengaruh 119 kali untuk mendapatkan nilai dengan kategori kurang baikdan mempunyai peluang sebesar $87 \%$. Dan selanjutnya sebagai saran penelitian dengan judul yang sama bias diterapkan dan dikembangkan dengan variable yang lain pada popilasi sekolah lainnya di Kota Kupang. 


\section{DAFTAR RUJUKAN}

[1] Dian, M., \& Ummu, A. (2020). Implementation of 21st-Century Learning on Psychomotor Learning Outcomes in Science Materials With Learning Motivation as Co-Variable. Atlantis Press, 1(1), 37-40.

[2] Ema Putri, R. (2015). Pengaruh Keterlibatan Orangtua Dalam Belajar Terhadap Prestasi Belajar Siswa Kelas V Sekolah Dasar Negeri Se-Daerah Binaan Iii Kecamatan Petarukan Kabupaten Pemalang. http://lib.unnes.ac.id/id/eprint/21484

[3] Kadir, A. (2012). Dasar-Dasar Pendidikan. Kencana, Jakarta.

[4] Meleong, J. (2009). Metode Penelitian Kualitatif. PT. Remaja Rosdakaya. Bandung.

[5] Notoatmodjo, S. (2012). Metodologi Penelitian Kesehatan. PT. Rineka Cipta, Jakarta.

[6] Rini, H., \& Suci, A. (2016). Pola Asuh Orang Tua Dan Lingkungan Pembelajaran Terhadap Motivasi Belajar Siswa. Jurnal Curricula, 1(2), 20-29.

[7] Sugiono, P. D. (2011). Metode Penelitian Kuantitatif Kualitatif dan $R \&$ D. CV.Alfabeta, Bandung.

[8] Sutardi, T. (2007). Antropologi: Mengungkap keragaman budaya. PT.Grafindo Media Pratama.

[9] Syamsi, S. (2015). Peningkatan Penguasaan Kosakata Bahasa Arab Melalui Metode Penugasan Model Contoh, Latihan, Kerja Mandiri (CLK). Al Ma'rifah (Jurnal Budaya,Bahasa Dan Sastra Arab), 12(2), $48-57$.

[10] Ummu, A., Sunimbar, S., \& Uslan, U. (2020). The Improvement of Science Learning Outcomes of Primary School Students Through the Model of POGIL-Supplemented With the Student Worksheet. Atlantis Press, 1(1), 181-188.

[11] Ummu, A., Suryadin, H., \& Uslan, U. (2020). The Influence of Process Oriented Guided Inquiry Learning (POGIL) Model Assisted by Realia Media to Improve Scientific Literacy and Critical Thinking Skill of Primary School Students. European Journal of Educational Research, 9(4), 1635-1647. 